\title{
The impact of General Dental Council registration and continuing professional development on UK dental care professionals: (1) dental nurses
}

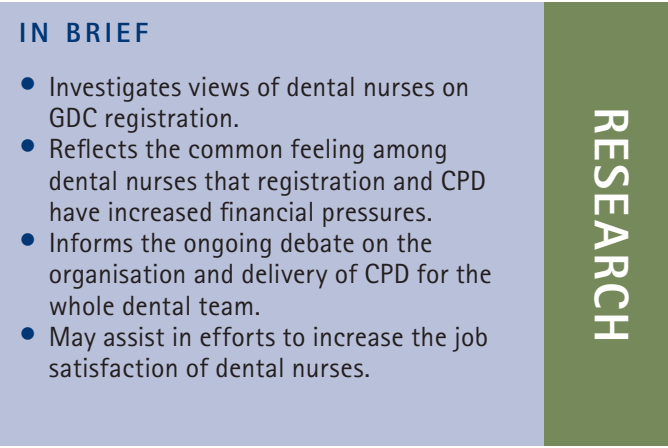

\author{
S. Turner, ${ }^{1}$ M. K. Ross ${ }^{2}$ and R. J. Ibbetson ${ }^{3}$
}

\begin{abstract}
Objective To investigate the impact of GDC registration and mandatory CPD on dental nurses' views, job satisfaction and intention to leave. Design Postal/online survey, conducted in parallel with a survey of dental technicians. Setting UK private and NHS practices, community services, dental hospitals. Subjects and methods Representative sample of General Dental Council registrants. Main outcome measures Job satisfaction; intention to leave profession (dependent variable in regression analysis). Results Eleven were ineligible (left profession, moved abroad); 267 (44\% of those eligible) responded, all female. Respondents' mean age was 38.2 years (sd 10.74). The general principle of registration was endorsed by 67\%, and compulsory registration by $51 \%$, but the fee level by only $6 \%$. Most nurses did not feel that registration had affected their view of dental nursing as a career (56\%), their role (74\%) or status (86\%) within the dental team, or that CPD helped them to do their job better (76\%). Fiftly-six percent were not satisfied with their job, and 22\% intended to leave the profession. Intention to leave was predicted by younger age and greater dissatisfaction with physical working conditions and opportunities to progress. Conclusions Widely held criticisms regarding the costs and relevance of registration and CPD coupled with a potentially high level of attrition from the profession suggest a review of the fee and salary structure and greater financial support for CPD is warranted.
\end{abstract}

\section{INTRODUCTION}

In July 2008 it became compulsory for dental nurses together with other previously unregistered dental care professional (DCP) groups working in the UK to register with the General Dental Council (GDC), involving payment of an annual registration fee and verification of qualifications. At the same time, mandatory continuing professional development (CPD) for DCPs was introduced. The GDC's rationale is that 'patients are right to expect that all members of the dental team are keeping their skills and knowledge up to date throughout their careers' ${ }^{1}$ and recommends that verifiable CPD should include medical emergencies, decontamination and disinfection, radiography and radiation protection, legal and ethical issues and complaint

${ }^{1^{*}-3}$ Edinburgh Postgraduate Dental Institute, University of Edinburgh, 4th Floor, Lauriston Building, Lauriston Place, Edinburgh, EH3 9HA

*Correspondence to: Stephen Turner

Email:s.turner@dundee.ac.uk

Online article number E2

Refereed Paper - accepted 25 May 2012

DOI: 10.1038/sj.bdj.2012.664

${ }^{\ominus}$ British Dental Journal 2012; 213: E2 handing. ${ }^{2}$ In July 2011 the GDC announced a review of the mandatory CPD scheme. ${ }^{2}$

A 2008 NHS Workforce Review Team (WRT) report on the English workforce indicated that the demand for dental nurses was likely to increase in light of the increase in dental graduates. ${ }^{3}$ By 2011 , dental nurses were the largest single professional group working in dentistry in the UK; the number registered growing from 36,240 in July 2008 to 47,436 in March 2012. ${ }^{4}$ According to the British Dental Association, by 2010 the average UK practice employed 2.4 whole time equivalent (WTE) dentists and 3.4 WTE dental nurses ( 4.3 by headcount, due to many working part-time). ${ }^{5}$

At the time there was considerable uncertainty over the impact of the 2008 reforms. On the one hand it was hoped that they would lead to dental nurses being better equipped to handle the demands of modern dental practice and bring them in line with other members of the dental team. Conversely there were fears that a rigid training programme and compulsory examinations could compound existing recruitment problems. ${ }^{6,7}$ A study of dental nurses in Scotland concluded that poor career prospects and remuneration could exacerbate the shortage of dental nurses. ${ }^{8}$ The 2008 WRT report suggested that many older, highly experienced dental nurses, or those thinking of returning to work after maternity breaks but with no qualifications, may leave the profession rather than submit to training and mandatory registration. The WRT noted that there was a context of high but unquantified attrition rates for dental nurses from general dental practice, due (at least in the South of England) to higher potential earnings and pension benefits in the hospital service, dental access centres and the community dental service. The Faculty of General Dental Practice (UK) suggested poor pay and career prospects contributed to attrition. ${ }^{3}$ In particular, loss to the profession could be anticipated through career progression into dental hygienetherapy posts. A 2005 national survey of dental hygiene and therapy training providers concluded that about $73 \%$ of their intake was drawn from the dental 
nurse workforce. ${ }^{9}$ In respect to $\mathrm{CPD}$, the WRT noted that funding streams for dental nurse education can be complex for employers to understand and that access to education varied geographically.

While GDC registration has led to improved monitoring of the workforce, there has been no systematic research into the impact, whether positive or negative, of these far-reaching changes for dental nurses and the dental teams in which they work, or the implications for workforce planning. A 2011 GDC-commissioned literature review of the impact of CPD noted 'there were far fewer studies on CPD for the other dental professions and of those for dental nurses and dental technicians none graded higher than 4 [well-organised, nonexperimental studies]. ${ }^{10}$ A 2011 literature review on dental practitioner performance by the NHS National Patient Safety Agency suggested that the employed status of dental nurses (in contrast to the generally self-employed status of hygienists and technicians) may cause dental nurses to feel less in control of their work environment and career, with potential implications for staff turnover. The review recommended further exploration of the possible differences in retention rates in different dental professional groups. ${ }^{11}$

In 2012, the GDC published the Electoral Reform Services Research survey of a representative sample of all GDC registrants regarding perspectives on mandatory CPD. ${ }^{12}$ of all registrant groups, dental nurses were least likely to undertake weekly CPD. While only 55\% of responding dental nurses said they paid for CPD courses themselves, 70\% said cost was a barrier for CPD completion. The survey did not address views on GDC registration, job satisfaction or career intentions.

The aim of the present study was to investigate the impact of GDC registration and mandatory CPD on the views, working practices, role within the dental team, training experience, job satisfaction and intention to leave dental nursing in a representative sample of dental nurses working in the UK.

\section{METHOD AND MATERIALS}

The GDC register of dental care professionals was obtained from the GDC in March 2011, subject to its sole use for the research purposes stated. After excluding dental nurses with a further qualification such as dental hygiene, a random sample was drawn and stratified by country. Those with non-UK addresses were also excluded.

A power calculation suggested that a sample size of 381 would give a confidence interval of $\pm 5 \%$ around a proportion of 0.5 . A sample of 635 was drawn, allowing for a $60 \%$ response rate. This was felt to be a realistic estimate of response rate, as it was slightly lower than that achieved in recent similar surveys of registered dental hygienists and therapists conducted by the authors. A preliminary letter included the address of an online survey provider (surveymonkey.com) where the survey questionnaire was accessible. The posting of a paper version of the questionnaire was followed by a second copy of the questionnaire and then a reminder/thank you postcard. As an incentive, respondents were entered into a draw for two £25 vouchers.

Job satisfaction was measured by the Warr-Cook-Wall scale, in which ten items are rated from 1 (extreme dissatisfaction) to 7 (extreme satisfaction). Reliability and validity data have been reported. ${ }^{13}$ The items all appeared to have good face validity with this sample, and a Chronbach alpha coefficient of 0.90 was obtained for the ten scores, indicating good reliability in this group. In particular, aspects of extrinsic job satisfaction (pay and conditions) have been identified as potential issues among dental nurses. ${ }^{3}$ The scale has been used in a number of studies and across different occupations, including UK dental primary care staff, allowing comparison with dental therapists and hygienists. ${ }^{14,15}$

Questions on career intentions, including intention to quit, were taken from the 2010 NHS staff survey in England undertaken by The Care Quality Commission, to permit comparisons with other professional groups working in primary care. ${ }^{16}$ All analysis was conducted using SPSS v17. Given the concerns over attrition of the dental nurse workforce cited earlier, predictors of responses of 'agree' or 'strongly agree' with the statement 'I plan to leave dental nursing for a different career' were explored, including job satisfaction domains, views regarding registration and $\mathrm{CPD}$, age and employment sector (ie private general dental practice, salaried service etc). Variables with a significant relationship with intention to leave were entered into a logistic regression analysis with intention to leave as the dichotomous dependent variable.

\section{RESULTS}

A total of 267 completed questionnaires were returned. Forty (15\%) were completed online (including five which were excluded as paper versions had also been returned). Eleven individuals were ineligible (left the profession, moved abroad), giving a final response rate of $44 \%$. All respondents were female. Their mean age was 38.2 years (sd 10.74), range 19-65.

\section{Employment}

Seventy-nine percent (209) worked in England, 10\% (28) in Scotland, 8\% (20) in Wales, and 3\% (8) in Northern Ireland. Length of service (not necessarily unbroken) ranged from 2 to 49 years (mean 15.7). All but 5\% (12) were employees. Just over half worked in mixed NHS/private general dental practices (Fig. 1).

Mean number of hours worked was 30.5 (sd 9.7): 25\% worked 22.5 hours or fewer, and $25 \%$ worked 38.0 hours or more.

\section{Qualifications}

The majority of nurses $(59 \%, 160)$ held the National Examining Board for Dental Nurses Qualification; 15\% (41) held NVQ level 3; 8\% (21) the National Examining Board for Dental Surgery Assistants Certificate; and 5\% (13) the City and Guilds level 3 Diploma. Eight percent (21) were qualified through verified competency. Fifteen percent (42) reported holding specialist qualifications, predominantly in radiography, oral health education and sedation.

\section{GDC registration}

Respondents were asked for their views on four aspects of GDP registration (Fig. 2).

Responses were generally favourable in regard to the general principle of registration, the requirement to complete CPD and for registration being compulsory, but very unfavourable regarding the level of the registration fee. In reply to a subsequent question 74\% (200) of dental nurses said the fee was 'much too high' and only $2 \%$ (5) said it was 'about right'.

Attitudes regarding the general principle of registration and it being compulsory were linked to employment sector. Those in NHS or mixed NHS/private general dental practices tended to be less favourable than 


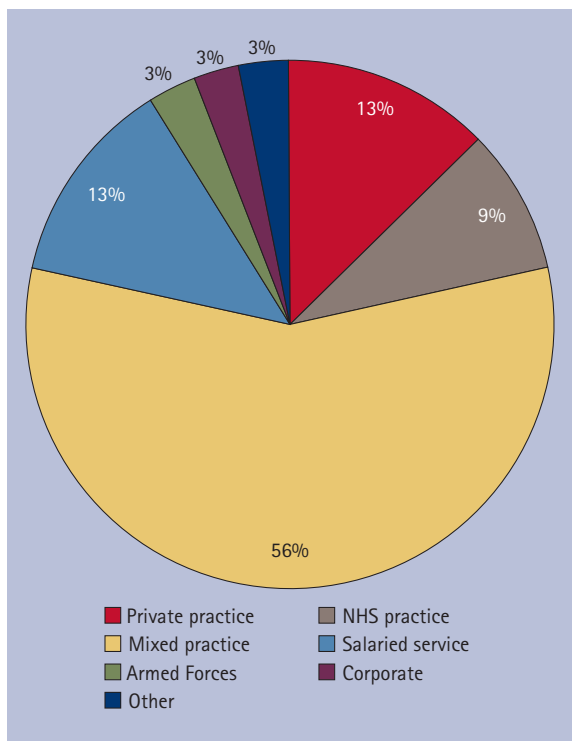

Fig. 1 Employment sector. $\mathrm{n}=\mathbf{2 6 4}$

those in salaried service, corporate, hospital and armed forces employment (ANOVA analysis of variance for general principle of registration: $\mathrm{F}=3.04, \mathrm{df}=4,258$, $\mathrm{p}=0.018$; for compulsory registration: $\mathrm{F}=2.45, \mathrm{df}=4,255, \mathrm{p}=0.047)$.

Nurses were asked what they felt the attitude of their employer was towards GDC registration for dental nurses: 39\% (105) felt their employer was very or quite favourable, 24\% (65) said they were neutral, 22\% (61) said they were very or quite unfavourable and 13\% (35) could not say (missing: 6). Again this related to sector, with nurses employed in NHS or mixed NHS/private general dental practices reporting more negative attitudes than those in non-general dental service positions $(\mathrm{F}=2.67, \mathrm{df}=4,220, \mathrm{p}=0.033)$.

\section{Impact of GDC registration}

Nurses were asked if the introduction of statutory registration had affected their view of dental nursing as a career, their role as a dental nurse or their status within the dental team. Those that responded positively to any of the three questions were asked how they had been affected (Fig. 3).

Negative impact regarding the impact on their career was overwhelmingly seen as financial in nature: $88 \%$ (51) of all negative comments referred to costs, while positive comments referred to increased professionalism $(60 \%, 23)$, greater respect or status $(25 \%, 10)$, and greater responsibility, knowledge or job interest (17\%, 7).

of the minority who felt that registration had affected their role as a dental

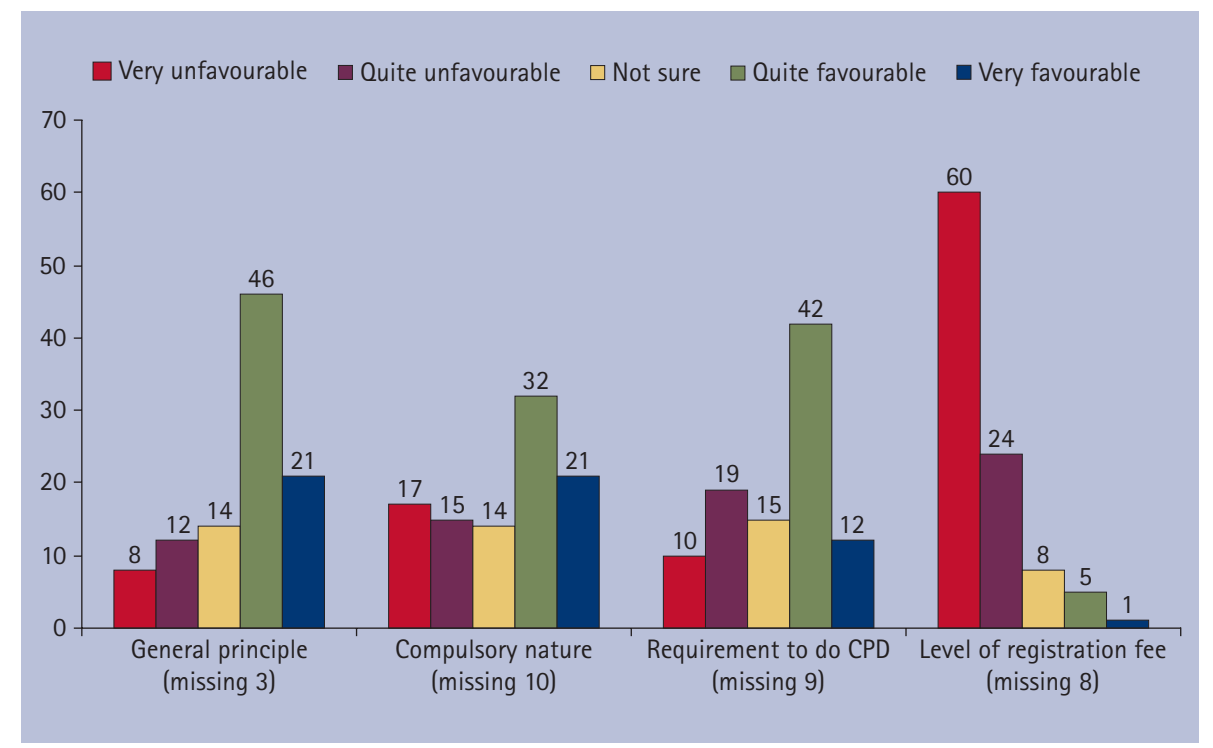

Fig. 2 Dental nurses' views on four aspects of GDC registration. $n=267$

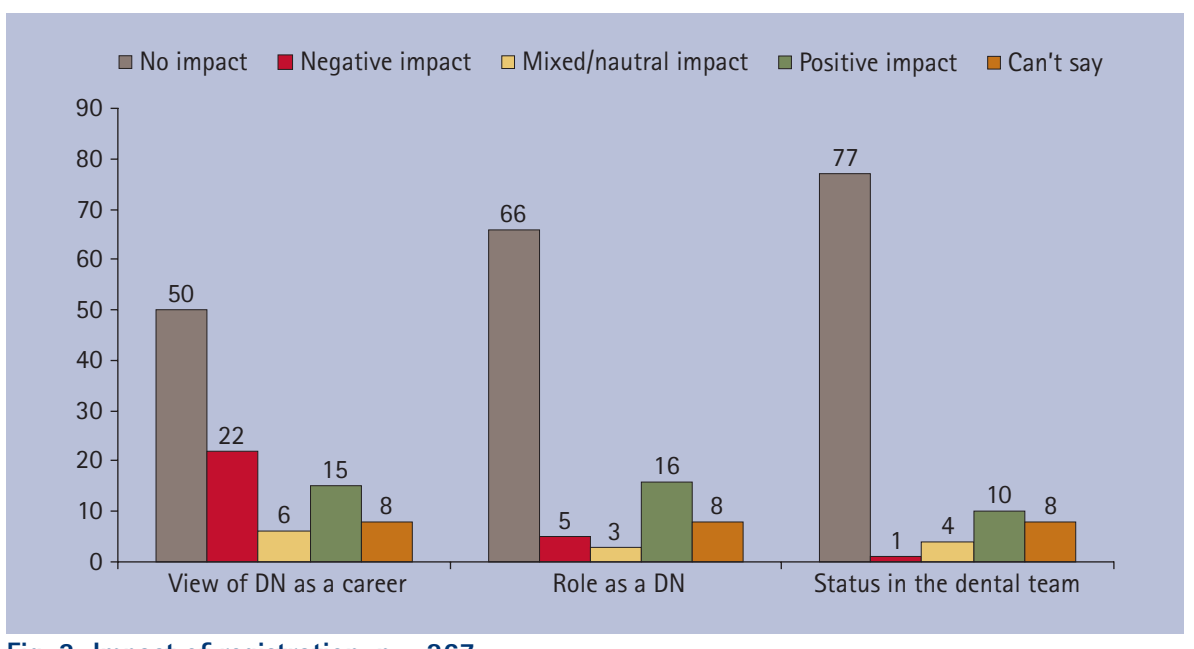

Fig. 3 Impact of registration. $\mathrm{n}=\mathbf{2 6 7}$

nurse, most saw the impact as being positive, commenting on their greater responsibility or awareness $(51 \%, 21)$, increased respect or status from colleagues or patients $(29 \%, 12)$, feeling more professional $(7 \%, 3)$, and increased knowledge or training $(12 \%, 5)$. Negative comments referred to financial costs $(46 \%, 6)$, increased pressure on time $(31 \%, 4)$, increased responsibility $(15 \%, 2)$, and less security $(8 \%, 1)$.

Although few felt there had been any impact on their status within the dental team, of those that did, most felt the impact to be positive. Those making positive comments mentioned being more involved, important, or respected within the team $(78 \%, 21)$, having more responsibility $(11 \%, 3)$, higher standards $(7 \%, 4)$, supporting the case for CPD training (1). Both negative comments referred to increased pressure on their time.

\section{CPD}

The mean number of CPD hours undertaken in 2010 was reported as 30.22 (sd: 26.19; missing: 83). Asked if they now did more or less CPD since it became mandatory, 52\% (136) said more, 5\% (14) said less and 36\% (93) said about the same amount (missing: 11). Funding of CPD was a problem for 41\% (105) of nurses (missing: 16). Over one third $(36 \%, 89)$ said they had to pay personally for all or some of their CPD, while others said they could only attend free courses. The most commonly cited courses were: medical emergencies and first aid (mentioned by 54\%: 147); decontamination and disinfection (31\%: 85); legal/ethical, including child protection (24\%: 66$)$; radiation and radiography (24\%: 65).

Nurses were asked three questions on training taken from the NHS 2010 Staff Survey (Table 1). Whilst generally agreeing 
that training had helped keep them upto-date, they were less in agreement with the statement that it 'helped them do their job better'

Asked if the introduction of mandatory CPD had affected their role as a dental nurse, 21\% (56) said it had, 71\% (187) said it had not and 8\% (9) were not sure. The first group cited greater pressure on their time $(38 \%, 18)$, greater knowledge or skills, or wider qualifications $(25 \%, 12)$, more responsibility $(13 \%, 5)$ and the cost of attending courses $(8 \%, 3)$. Other comments $(10 \%, 5)$ included shortage of courses and the possibility of leaving the profession.

Again only a minority $(18 \%, 47)$ felt that mandatory CPD had affected the range of clinical duties undertaken, while 77\% (204) said it had not and 5\% (14) could not say. The most common comment was that CPD had increased their clinical responsibilities and range of skills they employed $(84 \%, 37)$ (eg taking impressions and radiographs and applying fluoride varnish).

As with GDC registration, nurses were asked about the attitude of their employer towards CPD: 38\% (103) felt their employer was very or quite favourable, 28\% (75) said they were neutral, 19\% (52) said they were very or quite unfavourable and 13\% (35) could not say (missing: 7). As with dentists' attitudes towards registration, this related to sector, with the small number of nurses employed in non-general dental service positions reporting more positive attitudes on the part of their employing dentist than those in NHS or mixed NHS/private general dental practices or in the salaried service $(\mathrm{F}=2.98, \mathrm{df}=4,223, \mathrm{p}=0.020)$.

\section{Job satisfaction and career intentions}

Mean score on the 10-item job satisfaction scale was 4.78 (sd: $1.12, \mathrm{n}=266$ ). Taking the recognised cut-off of five or more on the seven point scale as indicating satisfaction, 44\% were found to be satisfied with their job. Figure 4 shows the variation across the ten satisfaction domains, and compares dental nurses with dental hygienists. ${ }^{15}$

Career support and intention to leave were investigated through a number of questions again taken from the NHS 2010 Staff Survey. As in Table 1, Tables 2 and 3 include responses from adult and general

Table 1 Views on the impact of post qualification training: dental nurses, adult nurses* and nursing assistants*

\begin{tabular}{|c|c|c|c|c|c|c|}
\hline \multicolumn{2}{|c|}{$\begin{array}{l}\text { My training, learning and development } \\
\text { has helped me to: }\end{array}$} & $\begin{array}{l}\text { Strongly } \\
\text { disagree }\end{array}$ & Disagree & $\begin{array}{l}\text { Neither } \\
\text { agree nor } \\
\text { disagree }\end{array}$ & Agree & $\begin{array}{l}\text { Strongly } \\
\text { agree }\end{array}$ \\
\hline \multirow{3}{*}{ Do my job better. } & Dental nurses & $8 \%$ & $16 \%$ & $30 \%$ & $36 \%$ & $10 \%$ \\
\hline & Adult/general nurses & $3 \%$ & $4 \%$ & $22 \%$ & $54 \%$ & $18 \%$ \\
\hline & Nursing assistants & $3 \%$ & $3 \%$ & $21 \%$ & $54 \%$ & $19 \%$ \\
\hline \multirow{3}{*}{$\begin{array}{l}\text { Stay up-to-date } \\
\text { with my job }\end{array}$} & Dental nurses & $5 \%$ & $7 \%$ & $19 \%$ & $56 \%$ & $14 \%$ \\
\hline & Adult/general nurses & $3 \%$ & $4 \%$ & $15 \%$ & $60 \%$ & $19 \%$ \\
\hline & Nursing assistants & $4 \%$ & $4 \%$ & $15 \%$ & $60 \%$ & $18 \%$ \\
\hline
\end{tabular}

"Source: NHS Staff Survey 2010, ${ }^{16}$ personal communication. Base numbers: dental nurses: 261-266; adult/general nurses: 5247-5274; nursing assistants: $3494-3,541$. The use of italics indicates where the difference in the agree/strongly agree
cant vis a vis the dental nurse sample (difference in proportions test, confidence level =99\%)

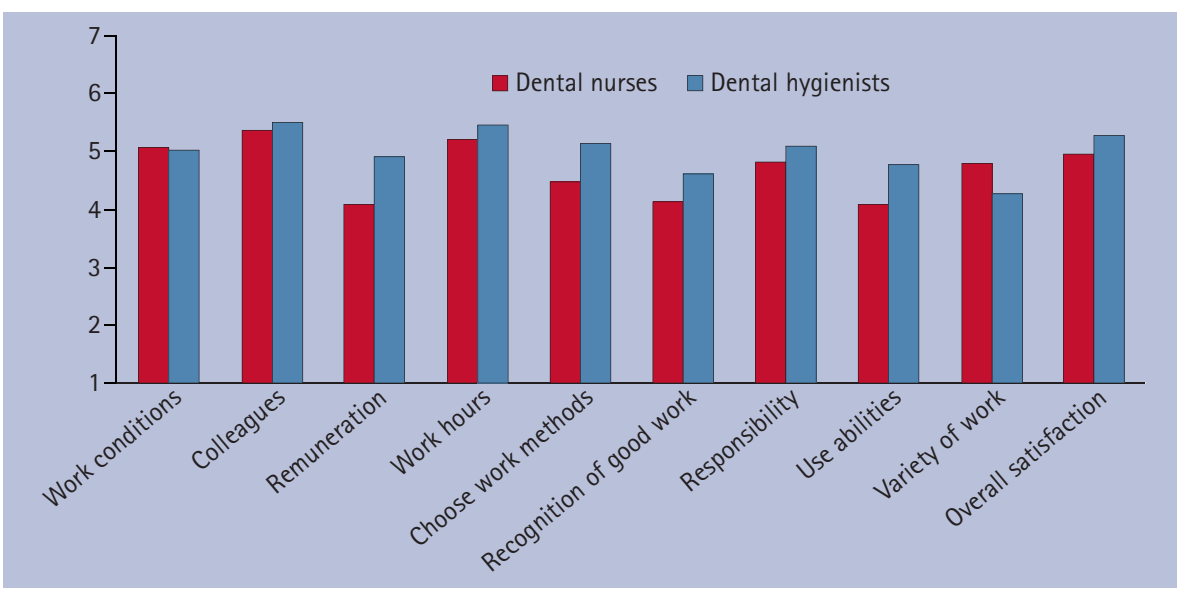

Fig. 4 Job satisfaction among dental nurses and dental hygienist-therapists

Table 2 Career development of dental nurses, adult nurses* and nursing assistants*

\begin{tabular}{|c|c|c|c|c|c|c|}
\hline & & $\begin{array}{l}\text { Strongly } \\
\text { disagree }\end{array}$ & Disagree & Neither & Agree & $\begin{array}{l}\text { Strongly } \\
\text { agree }\end{array}$ \\
\hline \multirow{2}{*}{$\begin{array}{l}\text { There are } \\
\text { opportunities for } \\
\text { me to progress } \\
\text { in my job. }\end{array}$} & Dental nurses & $14 \%$ & $25 \%$ & $27 \%$ & $28 \%$ & $6 \%$ \\
\hline & $\begin{array}{l}\text { Adult/general nurses } \\
\text { Nursing assistants }\end{array}$ & $\begin{array}{l}8 \% \\
12 \%\end{array}$ & $\begin{array}{l}25 \% \\
27 \%\end{array}$ & $\begin{array}{l}31 \% \\
27 \%\end{array}$ & $\begin{array}{l}32 \% \\
29 \%\end{array}$ & $\begin{array}{l}4 \% \\
5 \%\end{array}$ \\
\hline \multirow{2}{*}{$\begin{array}{l}\text { I am supported to } \\
\text { keep up-to-date } \\
\text { with developments } \\
\text { in my field. }\end{array}$} & Dental nurses & $7 \%$ & $15 \%$ & $27 \%$ & $40 \%$ & $11 \%$ \\
\hline & $\begin{array}{l}\text { Adult/general nurses } \\
\text { Nursing assistants }\end{array}$ & $\begin{array}{l}3 \% \\
4 \%\end{array}$ & $\begin{array}{l}11 \% \\
13 \%\end{array}$ & $\begin{array}{l}20 \% \\
24 \%\end{array}$ & $\begin{array}{l}57 \% \\
52 \%\end{array}$ & $\begin{array}{l}9 \% \\
7 \%\end{array}$ \\
\hline \multirow{2}{*}{$\begin{array}{l}\text { I am encouraged } \\
\text { to develop my } \\
\text { own expertise. }\end{array}$} & Dental nurses & $9 \%$ & $19 \%$ & $26 \%$ & $35 \%$ & $10 \%$ \\
\hline & $\begin{array}{l}\text { Adult/general nurses } \\
\text { Nursing assistants }\end{array}$ & $\begin{array}{l}3 \% \\
4 \%\end{array}$ & $\begin{array}{l}9 \% \\
13 \%\end{array}$ & $\begin{array}{l}21 \% \\
29 \%\end{array}$ & $\begin{array}{l}56 \% \\
47 \%\end{array}$ & $\begin{array}{l}11 \% \\
7 \%\end{array}$ \\
\hline \multirow{2}{*}{$\begin{array}{l}\text { There is strong } \\
\text { support for training } \\
\text { in my area of work. }\end{array}$} & Dental nurses & $9 \%$ & $18 \%$ & $29 \%$ & $34 \%$ & $10 \%$ \\
\hline & $\begin{array}{l}\text { Adult/general nurses } \\
\text { Nursing assistants }\end{array}$ & $\begin{array}{l}5 \% \\
5 \%\end{array}$ & $\begin{array}{l}14 \% \\
15 \%\end{array}$ & $\begin{array}{l}26 \% \\
30 \%\end{array}$ & $\begin{array}{l}44 \% \\
41 \%\end{array}$ & $\begin{array}{l}10 \% \\
8 \%\end{array}$ \\
\hline \multirow{2}{*}{$\begin{array}{l}\text { I plan to get further } \\
\text { qualifications. }\end{array}$} & Dental nurses & $6 \%$ & $14 \%$ & $35 \%$ & $26 \%$ & $19 \%$ \\
\hline & \multicolumn{6}{|c|}{ Adult/general nurses/Nursing assistants: NA } \\
\hline
\end{tabular}

nurses and from nursing or healthcare assistants working in primary care trusts in England. ${ }^{14}$ Dental nurses were also asked whether they intended to seek further qualifications and whether they planned to leave the profession.

Of the three groups, dental nurses were consistently more likely to give negative 


\begin{tabular}{|c|c|c|c|c|c|c|}
\hline & & $\begin{array}{l}\text { Strongly } \\
\text { disagree }\end{array}$ & Disagree & Neither & Agree & $\begin{array}{l}\text { Strongly } \\
\text { agree }\end{array}$ \\
\hline \multirow{2}{*}{$\begin{array}{l}\text { I often think about } \\
\text { leaving this post. }\end{array}$} & Dental nurses & $21 \%$ & $24 \%$ & $22 \%$ & $20 \%$ & $19 \%$ \\
\hline & $\begin{array}{l}\text { Adult/general nurses } \\
\text { Nursing assistants }\end{array}$ & $\begin{array}{l}12 \% \\
18 \%\end{array}$ & $\begin{array}{l}33 \% \\
33 \%\end{array}$ & $\begin{array}{l}25 \% \\
26 \%\end{array}$ & $\begin{array}{l}22 \% \\
17 \%\end{array}$ & $\begin{array}{l}9 \% \\
7 \%\end{array}$ \\
\hline \multirow{2}{*}{$\begin{array}{l}\text { I will probably look } \\
\text { for a job at a new } \\
\text { organisation in the } \\
\text { next } 12 \text { months. }\end{array}$} & Dental nurses & $28 \%$ & $22 \%$ & $23 \%$ & $17 \%$ & $11 \%$ \\
\hline & $\begin{array}{l}\text { Adult/general nurses } \\
\text { Nursing assistants }\end{array}$ & $\begin{array}{l}13 \% \\
20 \%\end{array}$ & $\begin{array}{l}33 \% \\
37 \%\end{array}$ & $\begin{array}{l}27 \% \\
25 \%\end{array}$ & $\begin{array}{l}18 \% \\
12 \%\end{array}$ & $\begin{array}{l}9 \% \\
6 \%\end{array}$ \\
\hline \multirow{2}{*}{$\begin{array}{l}\text { As soon as I can } \\
\text { find another job, I } \\
\text { will leave this post. }\end{array}$} & Dental nurses & $32 \%$ & $26 \%$ & $23 \%$ & $12 \%$ & $7 \%$ \\
\hline & $\begin{array}{l}\text { Adult/general nurses } \\
\text { Nursing assistants }\end{array}$ & $\begin{array}{l}17 \% \\
23 \% \\
\end{array}$ & $\begin{array}{l}36 \% \\
39 \%\end{array}$ & $\begin{array}{l}28 \% \\
25 \%\end{array}$ & $\begin{array}{l}11 \% \\
8 \%\end{array}$ & $\begin{array}{l}7 \% \\
5 \% \\
\end{array}$ \\
\hline \multirow{2}{*}{$\begin{array}{l}\text { I plan to leave } \\
\text { dental nursing for a } \\
\text { different career. }\end{array}$} & Dental nurses & $28 \%$ & $24 \%$ & $26 \%$ & $12 \%$ & $10 \%$ \\
\hline & \multicolumn{6}{|c|}{ Adult/general nurses/Nursing assistants: NA } \\
\hline
\end{tabular}

Table 4 Predictors of intention to leave dental nursing profession

\begin{tabular}{|c|c|c|c|c|c|}
\hline & $t\left(X^{2}\right)$ & $d f$ & $\mathrm{p}$ & \multicolumn{2}{|c|}{$\begin{array}{l}95 \% \mathrm{Cl} \text { of difference } \\
\text { lower upper }\end{array}$} \\
\hline \multicolumn{6}{|l|}{ Unfavourable view of: } \\
\hline general principle of registration & 2.270 & 259 & 0.024 & 0.725 & 0.051 \\
\hline mandatory CPD & 2.757 & 255 & 0.006 & 0.802 & 0.139 \\
\hline level of registration fee & 2.251 & 134.687 & 0.026 & 0.457 & 0.030 \\
\hline Employer's unfavourable view of CPD & 2.855 & 223 & 0.005 & 0.539 & 0.019 \\
\hline Funding CPD is a problem & $(8.350)$ & 1 & 0.004 & & \\
\hline \multicolumn{6}{|l|}{ Lower job satisfaction re: } \\
\hline physical working conditions & 4.510 & 78.019 & 0.000 & 1.314 & 0.432 \\
\hline remuneration & 2.152 & 242 & 0.032 & 1.062 & 0.047 \\
\hline hours of work & 2.300 & 259 & 0.022 & 0.866 & 0.067 \\
\hline freedom to choose work method & 2.526 & 80.120 & 0.014 & 1.098 & 0.130 \\
\hline recognition for good work & 3.813 & 259 & 0.000 & 1.468 & 0.468 \\
\hline opportunity to use abilities & 2.085 & 258 & 0.038 & 0.901 & 0.026 \\
\hline amount of variety in job & 3.073 & 78.784 & 0.003 & 1.236 & 0.264 \\
\hline overall feeling about job & 4.934 & 259 & 0.000 & 1.530 & 0.657 \\
\hline \multicolumn{6}{|l|}{ Disagree that: } \\
\hline are opportunities to progress & 3.417 & 260 & 0.001 & 0.905 & 0.243 \\
\hline is supported to keep up-to-date & 2.520 & 258 & 0.012 & 0.714 & 0.088 \\
\hline is encouraged to develop expertise & 3.003 & 261 & 0.003 & 0.824 & 0.171 \\
\hline is support for training in work area & 3.554 & 261 & 0.000 & 894 & 0.256 \\
\hline Age & 2.051 & 256 & 0.041 & 6.331 & 0.129 \\
\hline
\end{tabular}

responses, although for several items the difference was marginal.

In order to identify predictors of intention to leave dental nursing (as opposed to leave their current post), the $22 \%$ (59) of nurses who gave a response of 'agree' or 'strongly agree' to the statement 'I plan to leave dental nursing for a different career', were compared across a range of possible predictors to those who did not indicate such an intention. Results are shown in Table 4.

The three variables shown in italics remained significant in a logistic regression analysis using all the variables shown in Table 4 as independent predictors of intention to leave the profession. The model suggests that nurses who were less satisfied with their physical working conditions, did not feel there were opportunities to progress in their job and were younger, were more likely to intend to leave dental nursing for a different career $(B=-0.399, d f=3, p=001)$.

\section{Open-ended comments}

Dental nurses were asked to give any final comments they had on the issues raised by the survey. A total of 51 comments were given by 42 dental nurses $37 \%$ of the total). One quote has been chosen at random to illustrate each of the themes that emerged.

Twenty-seven comments referred to the level of the registration fee, including eight which suggested that the fees should be pro-rata for part time or junior nurses, and three which suggested monthly payment arrangements.

'The only real issue I have is the $£ 120$ registration fee, I know that myself and my work colleagues feel this is an extremely high fee to pay, also we would like to know what the $£ 120$ covers?'

Thirteen comments referred to dental nurses' poor pay or conditions;

'national wage increase or considerable reduction in fees or CPD requirements.'

Eight criticised the requirement for, inadequacy, cost, poor provision, or inaccessibility of CPD courses.

' $C P D$ requirements should be less as most nurses have to complete this in their own time and from their own pocket.'

Three further negative comments criticised the GDC's role and resulting bureaucracy'

'I have quite a negative view about the GDC commitment to supporting dental nurses.'

Finally, four positive comments were made about the values of training: however, all four were qualified by remarks about the cost of training or registration.

'CPD's have helped with my continuing education and helping me get into 
university to study to become a hygienist. I don't think it's right paying.'

\section{DISCUSSION}

The response rate achieved of 44\% was less than the 65\% reported in recent surveys of UK dental hygienists, hygienisttherapists and therapists. ${ }^{14,15}$ A survey of dental nurses in Scotland undertaken before registration that became compulsory also achieved a response rate of $65 \%{ }^{8}$ However, the response rate in the present study is comparable to the $43 \%$ achieved in a convenience sample of dental nurses attending courses or meetings in Northern Ireland and The Netherlands. ${ }^{17}$ One tactic employed to try to raise the response rate was providing an online version of the survey questionnaire. However, only 6\% of those contacted and 14\% of respondents took advantage of this facility. Possible reasons for lack of online participation include fears concerning lack of security of information, lack of access to an internet link and the inconvenience of manually entering the web address when compared to clicking on a link embedded in an e-mail. The use of a commercial survey company rather than a university-based facility may have also reduced uptake. Despite these limitations, this randomised survey of dental nurses appears to be the first in the UK since the 2008 reforms. No comparable studies of this professional group post 2008 were found in a broad literature search using numerous related terms. The final sample size of 267 gives a confidence interval of $\pm 6 \%$ around a proportion of 0.5 .

While two-thirds of dental nurses were in favour of the general principle of registration, only just over half agreed with registration or CPD being compulsory. A large majority did not feel that compulsory registration had positively affected their role or status at work, or their view of dental nursing as a career. Very strong negative feelings were expressed regarding the cost of registration with the GDC and the cost of CPD. Many perceived it to be unjust that dental nurses are required to pay the same annual retention fee as DCPs who undertake active intra-oral clinical work with patients, and that the costs of registration and CPD are unrelated to hours worked or income. In addition, it is reportedly difficult for many individuals to access CPD.
This is particularly evident in dental nurses practicing in remote or rural areas, where the nearest centre for education may be a significant distance away. ${ }^{8}$ Those with families are particularly disadvantaged by the fact that much dental nurse education takes place in the evening following a day in general practice. Despite these problems of cost and access, the amount and subject matter of CPD courses reported by dental nurses in the study generally conformed with that expected by the GDC.

Only a minority (44\%) of respondents were satisfied with their job, based on the recognised threshold of 5 on the Warr-Cook-Wall job satisfaction scale. This compares with 56\% of dually qualified hygienist-therapists who took part in a similar study. ${ }^{18}$ Satisfaction with their remuneration was particularly low, and was considerably less than that reported in the study of dental hygienist-therapists. Other areas where satisfaction was particularly low were recognition received for good work and the opportunity to use their abilities.

Almost one-quarter of respondents expressed an intention to leave the dental nursing profession. If this is representatative of all dental nurses and half of those voicing an intention to leave actually do so in the following 12 months, it would mean that over 5,000 will leave the profession every year. Results from the study suggest such attrition may disproportionally involve younger dental nurses, implying a loss of investment in training and contradicting the NHS Workforce Review Team's suggestion that older dental nurses may leave the profession to avoid training and mandatory registration. ${ }^{3}$ Given the strength of dental nurses' negative feelings regarding the cost of registration and CPD courses, it is perhaps surprising that no financial factors predicted intention to leave. One explanation could be that dissatisfaction with the registration fee was almost universal and this lack of variance prevented it from acting as a predictor of intention to leave. The study findings are in agreement with those from other studies that job satisfaction is a key determinant of intention to leave. ${ }^{19,20}$

The results of the present study are supported by the GDC's recent investigation of attitudes towards CPD. ${ }^{12}$ That survey found that only 19\% of dental nurses agreed that they found it easy to take time off for CPD, the lowest proportion of all registrant groups apart from dental technicians. Nurses and dental technicians also had the lowest level of agreement with the statements 'I find it easy to find the motivation to undertake CPD' (39\% and 36\% respectively), and 'I would do CPD even if it was not mandatory' (47\% in both cases). Both groups tended to see CPD as a requirement to maintain registration rather than as a means to become more professional. Only $40 \%$ of dental nurses felt that verifiable CPD had taught them new skills. This finding supports that of the present study indicating that dental nurses were far less likely than other comparable groups to feel that post qualification training had helped them do their job better (Table 1).

Dental nurses are an indispensable part of the dental team and are vital to safe and successful practice. Historically, they have evolved from being chairside assistants, often without formal training, to skilled professionals who are qualified, registered and kept up-to-date through CPD, with many holding additional qualifications. Perhaps their status in the dental world has accelerated without necessarily being supported by appropriate remuneration and support. The aspiration of the GDC to have all DCPs either qualified or in training and statutorily registered is commendable, but perhaps the process has not received sufficient scrutiny. Our results demonstrate that a significant number of dental nurses are responsible for their own costs relating to CPD, which may be seen as inequitable, given the comparatively high income of their employers. Two further points may be of interest. Firstly, the annual retention fee for registration payable by general medical nurses to the General Nursing Council is currently $£ 76$, which is $37 \%$ less than the comparable fee paid by dental nurses. This situation seems rather inappropriate given that general medical nurses are often involved in more invasive and complex treatments, including the direct administration of drugs. Secondly, simple arithmetic reveals that the annual revenue derived by the GDC from dental nurses' annual retention fees is in excess of $£ 5.5 \mathrm{~m}$, given they are numerically the largest registrant group. 
Two studies which predate the 2008 reforms report many of the issues identified in the present study. ${ }^{8,21}$ These include lack of time, the lack of a supportive culture for nurses' CPD, and negative attitudes among employing GDPs. The study by Mercer et al. for the Yorkshire Deanery concludes '...there is a need to promote an ethos of lifelong learning within the practice setting for the whole dental team: ${ }^{21}$ Five years later this recommendation remains equally relevant. For dental nursing to develop further as a profession, there is a need to ensure that opportunities for education and career development are not undermined by remuneration levels disproportionate to the level of competence required for professional status and high quality patient care.

1. General Dental Council. Continuing professional development. Online information available at http:// www.gdc-uk.org/Dentalprofessionals/CPD/Pages/ default.aspx (accessed December 2011).

2. General Dental Council. Continuing professiona development for dental care professionals 2011. http://www.gdc-uk.org/Newsandpublications/ Publications/Publications/CPD\%20for\%20DCPs\%20 Feb12.pdf (accessed July 2012).

3. Centre for Workforce Intelligence. Workforce Summary - Dental Nurses 2008 - England only. http://www.cfwi.org.uk/intelligence/ previous-projects/workforce-summaries/dentalnurses (accessed July 2012).

4. General Dental Council. GDC registrant numbers reach record high. Press release. http://www.gdc-uk. org/Newsandpublications/Pressreleases/Pages/ GDC-registrant-numbers-reach-record-high.aspx (accessed July 2012). 2012 figure: GDC, personal communication, March 2012.

5. British Dental Association. BDA business trends survey. London: BDA, 2010. Online information available at http://www.bda.org/dentists/policycampaigns/research/workforce-finance/dcps/dcpworkforce.aspx (accessed December 2011).

6. John J H, Thomas D, Richards D, Evans C. Regulating dental nursing in the UK. Br Dent J 2002; 193: 207-209.

7. British Dental Journal. GDC requirements could harm nurse recruitment, suggests former member. Br Dent J 2008; 204: 424.

8. Ross M K, Ibbetson R J. Educational needs and employment status of Scottish dental nurses. Br Dent J 2006; 201: 661-666

9. National Dental Workforce Unit. The recruitment of dental nurses to dental hygiene and dental therapy training programmes. National Dental Workforce Unit, 2005.

10. Eaton $K_{1}$ Brookes J, Patel R, Batchelor P, Merali $F_{1}$ Narain M. The impact of continuing professional development in dentistry: a literature review. London: General Dental Council, 2011. Online article available at http://www.fgdp.org.uk/_assets/ pdf/research/final\%20impact $\% 20$ of\%20cpd\%20 on\%20dentistry\%20november\%202011.pdf (accessed June 2011)

11. National Clinical Assessment Service, National Patient Safety Agency. Factors influencing dental practitioner performance: a literature review. London: National Clinical Assessment Service, 2011.

12. Electoral Reform Research. Registrant and provider perspectives on mandatory CPD in dentistry in the UK. London: General Dental Council, 2012.
Online article available at http://www.gdc-uk.org/ Aboutus/Researchandconsultations/cpdreview/ Documents/Registrant\%20and\%20Provider\%20 Perspectives $\% 20$ on\%20Mandatory\%20CPD\%20 in $\% 20$ Dentistry\%20in\%20the\%20UK.pdf (accessed June 2012).

13. Warr P, Cook J, Wall T. Scales for the measurement of some work attitudes and aspects of psychological well-being. J Occup Psychol 1979; 52: 129-148.

14. Turner S, Ross M K, lbbetson R J. Job satisfaction among dually qualified dental hygienist-therapists in UK primary care: a structural model. Br Dent J 2011; 210: E5

15. Turner S, Ross M K, lbbetson R J. Dental hygienists and therapists: how much professional autonomy do they have? How much do they want? Results from a UK survey. Br Dent J 2011; 210: E16.

16. Care Quality Commission. 2010 NHS staff survey. Online article available at http://www.nhsstaffsurveys.com/cms/ (accessed December 2011).

17. Gorter R C, Bleeker J C, Freeman R. Dental nurses on perceived gender differences in their dentist's communication and interaction style. Br Dent J 2006; 201: 159-164.

18. Turner S, Ross M K, Ibbetson R J. Dually qualified dental hygienist-therapists: an underused resource? Presentation at British Association of Community Dentistry Conference, London: September 2009.

19. Shields M A, Ward M. Improving nurse retention in the National Health Service in England: the impact of job satisfaction on intentions to quit. J Health Econ 2001; 20: 677-701.

20. van der Heijden B I J M, van Dam K, Hasselhorn H M Intention to leave nursing: the importance of interpersonal work context, work-home interference, and job satisfaction beyond the effect of occupational commitment. Career Dev Int 2009; 14: 616-635.

21. Mercer P, Bailey H, Cook P. Perceptions, attitudes and opinions of general dental practitioners and dental nurses to the provision of lifelong learning for the dental team. Br Dent J 2007; 202: 747-753. 